\title{
Irrigation with Waste Water Treated by Constructed Wetlands
}

\author{
Mahboobe Ghasemi-Zaniani ${ }^{1}$, Saeid Eslamian ${ }^{2}$, Kaveh Ostad-Ali-Askari ${ }^{3 *}$, Vijay P. Singh ${ }^{4}$ \\ ${ }^{I}$ Department of Water Engineering, ShahidChamran University of Ahvaz, Ahvaz Iran. \\ ${ }^{2}$ Department of Water Engineering, Isfahan University of Technology, Isfahan, Iran. \\ ${ }^{3}$ Department of Civil Engineering, Isfahan (Khorasgan) Branch, Islamic Azad University, Isfahan, Iran. \\ ${ }^{4}$ Department of Biological and Agricultural Engineering \& Zachry Department of Civil Engineering, Texas A \\ and M University, 321 Scoates Hall, 2117 TAMU, College Station, Texas 77843-2117, U.S.A. \\ *Corresponding Author: Dr. KavehOstad-Ali-Askar, Department of Civil Engineering, Isfahan \\ (Khorasgan) Branch, Islamic Azad University, Isfahan, Iran.

\begin{abstract}
The use of wastewater in agricultural irrigation has the potential for positive and negative environmental impacts. With careful planning and management, the use of wastewater can be beneficial to the environment. Constructedwetlands are usedworldwideforwastewater treatment, and this study discussesthe resultsofthesewetlandsincold and moderateregions ofthe world.Results show a remarkable BOD5 removal efficiency (58.8-99.84\% of the influent BOD5 concentration), even though only $62 \%$ of these wetlands were constructed following the U.S. EPA guidelines. The constructed wetlands can help remove TSS up to a level that is compatible with the quality standards for most reuse application in irrigation of crops. These wetlands cannot provide a water reclamation solution from a microbiological quality perspective that can meet reuse quality standards for irrigation.In terms of acidity, the effluent from constructed wetlands in cold climate is appropriate for irrigation of all crops. As a result, for reusing constructed wetland effluent in irrigation, combined systems like WSP-CW system require complying with the standard effluent for reuse water
\end{abstract}

Keywords: Constructed wetlands, feasibility, irrigation, removal efficiency, reuse water

\section{INTRODUCTION}

The use of wastewater in agricultural irrigation has the potential for positive as well as negative environmental impacts. With careful planning and management, the use of wastewater in agricultural irrigation can be beneficial to the environment. Wastewater is an important source of water and nutrients for many farmers in arid and semi-arid climates. Sometimes it may be the only source of water available for agricultural irrigation. When Wastewater use is well managed, it helps recycle nutrients and water and therefore diminishes the cost of fertilizers or simply makes them accessible to farmers (WHO, 1991).

The rapid population growth in many cities or towns in the world has increased not only the demand for freshwater but also the volume of wastewater discharge. As other sources of water are decreasing, treated wastewater appears to be the only water resource that is increasing. In the development of new strategies for freshwater supply, the treatment and recycling of wastewater can play an important role in addressing water shortage. Reuse of treated wastewater for irrigating landscapes is often viewed as one of the approaches to maximize the existing water resources and to expand urban water supplies (U.S. EPA, 2004a). The exiting pollutants may have significant negative impacts on the surrounding environment and may endanger the ecosystem and public health. The proper treatment of wastewater before it is discharged into the environment may help mitigate these dangers. With the development of treatment systems, domestic wastewater can primarily be considered for reuse in agricultural irrigation. Nowadays, as more developed technologies are used for water reclamation, the quality of recycled water can match or even exceed drinking water quality, based on most conventional parameters. The conventional treated wastewater process includes a series of physical, chemical and biological processes. Typically, treatment includes three stages, known as primary, secondary and tertiary treatment. Primary treatment, that includes screening, grit removal, and primary sedimentation, is applied to separate and remove inorganic materials and suspended solids that harm 
the pipes. Secondary treatment cleans dissolved and suspended biological matter. Typically, up to $90 \%$ of the organic matter in the wastewater can be cleaned via tertiary treatment which is sometimes defined as advanced treatment. The tertiary treatment is the final treatment stage to raise the effluent quality to the expected level. Before discharging treated wastewater, a disinfection process is sometimes needed. The purpose of disinfection in the treatment of wastewater is to substantially reduce the number of microorganisms in the water to be discharged back into the environment, and it is almost always the final stage in the treatment process regardless of the level or type of treatment applied. The treated water can be discharged into a river, lagoon, or wetlands, or it be applied for landscape irrigation. If it is probably cleaned, it can also be used for groundwater recharge or agricultural purposes.

\subsection{History of Constructed Wetlands}

Investigations into the use of constructed wetlands (CWs) for wastewater treatment started in the middle of the last century. The first investigations were probably conducted by Käthe Seidel in Germany in the early 1950s at the Max Planck Institute in Plön (Seidel, 1955). Her report discussed the possibility "of lessening the over fertilization, pollution and silting up of inland waters through appropriate plants, thereby allowing the contaminated waters to support life once more" (Seidel, Happel, \&Graue, 1978, p. 2). It was clarified that macrophytes (e.g., Schoenoplectuslacustris) were capable of removing large quantities of organic and inorganic substances from polluted waters. Moreover, Schoenoplectus spp. not only enriched the soil in which grew bacteria and humus but apparently removed antibiotics. Bacteria and heavy metals in the polluted water were removed by passing through the macrophytes.

In North America, experimentation with FWS wetlands started with the observation of assimilative capacity of natural wetlands at the end of the 1960s and the beginning of the 1970s (Spangler, Sloey, \& Fetter, 1976; Wolverton, 1987). Between 1967 and 1972, a five-year study started in Chapel Hill, North Carolina, that used a composition of constructed coastal ponds and natural salt marshes for the recycling and reuse of municipal wastewater (Odum, 1977). In 1973, the first fully CW made up of a series of constructed marshes, ponds and meadows was built in Brookhaven, New York (Kadlec\& Knight, 1996). About the same time, an interdisciplinary research team at the University of Michigan started the Houghton Lake project. This research was the first application of a treatment wetland in a cold climate area (Kadlec, et al., 1975; Kadlec\& Tilton, 1979). Since then, FWS CWs have been expanded in the United States for various types of wastewater treatment. A CW is a low energyconsumption ecosystem. This wetland system uses natural biogeochemical cycles to eliminate sediments and pollutants from wastewater. Unlike complex high-maintenance treatment systems, the use of CWs will lead to a more ecologically-sustainable wastewater treatment in the future. This system provides an advanced treatment of wastewater that pretreats to secondary level. The pollutant removal efficiency is associated with multiple factors, including temperature, the size and number of wetlands, the volume and quality of influent water, and the retention time.

CWs are engineered that mimic natural wetlands that are gniebincreasingly considered for wastewater treatment worldwide. Constructed wetlands are constructed to utilize the natural processes that involve wetland vegetation, soils, and associated microbial assemblages for assisting with the treatment of wastewaters. CWs may be classified according to the life form of the dominating macrophyte, wetland hydrology (free water surface and subsurface systems), and subsurface flow CWs can be classified according to the flow direction (horizontal and vertical) (Vymazal, 2010).

\subsection{Advantages and Disadvantages of Conventional Treatment}

A conventional sewage treatment system needs relatively less land area and provides a better control of the wastewater treatment process. For example, CWs require 4 to 10 times more land area than does a conventional wastewater treatment facility (U.S. EPA, 1988). The treatment facilities usually work under a well-controlled environment. Thus, this system is less sensitive to the environment. The high cost of construction and maintenance is the main disadvantage of conventional wastewater treatment systems. Also, the management and monitoring of mechanical systems require expert personnel. Generally, the complication and cost of wastewater treatment technologies increase with the quality of reclamation produced (Organization of American States, 1997, Ostad-Ali-Askari et al., 2015., Bahmanpour et al., 2017., Dehghan et al., 2017). Table 1 shows advantages and disadvantages of FWS and SSF. 
Table1: Advantages and Disadvantages of Free Water Surface (FWS) Constructed Wetlands and Subsurface Flow (SSF) Wetlands

\begin{tabular}{|c|l|l|}
\hline \multirow{3}{*}{ Advantages } & \multicolumn{1}{|c|}{ FWS } & \multicolumn{1}{c|}{ SSF } \\
\cline { 2 - 3 } & Lower installation and operating costs & Greater assimilation rate, less land required \\
\cline { 2 - 3 } & $\begin{array}{l}\text { Good integration into landscape } \\
\text { More Secondary benefits(such as wildlife } \\
\text { habitat), but contamination exposure concern }\end{array}$ & More cold tolerant \\
\cline { 2 - 3 } & $\begin{array}{l}\text { Shorter development period to reach full } \\
\text { performance }\end{array}$ & Reduction in odor and insect problems \\
\hline $\begin{array}{c}\text { Disadvanta } \\
\text { ges }\end{array}$ & Less cold tolerant & Not attractive to wildlife \\
\cline { 2 - 3 } & More land required & more isolated from humans \\
\hline
\end{tabular}

\subsection{Cold Climate}

Important physical processes, such as sedimentation and decantation, and in particulate organic matter removal, are mostly not affected by winter conditions. However, biological processes are dependent on temperature, and winter removal efficiency of HSSFCWs for nitrogen and soluble organic matter that both are highly affected by biological activity, and may be reduced (Plamondon et. al. (2006), Eslamian et al., 1999., Eslamian et al., 2001., Eslamian et al., 2005).

Wastewater treatment by wetlands rely largely on biological and biochemical processes. Since hydraulics, and chemical and biochemical processes cause a possible decrease of dormant plants and a slow response rate of soil or aquatic microbes at low temperatures, these are considerably affected by cold winter climate (Maehlum et. al. (1995)). Because wetland treatment is usually land focused, it can be concluded that wetland treatment is more dependent on climatic conditions than are conventional wastewater treatment methods. Though the wide opinion for successful wetland treatment is for the warm regions, but studies in North America and Scandinavia have indicated that wetland treatment may also be possible in cool regions. Hence, wetland treatment can be accepted as a serious alternative method for treatment or as a supplement to more conventional methods in a number of treatment situations (Wittgren and Mrehlum (1997), Ostad-Ali-Askari et al., 2016, Eslamian et al., 2006).

Since treatment in SSF wetlands occurs below the ground surface, these wetlands have an advantage in colder climate. The reason is that treatment happens below the ground surface, and bacterial activity is thereby protected somewhat from the frigid air (Wittgren and Maehlum, 1997, Ostad-AliAskari et al., 2017, Eslamian et al., 2010).Wetland systems used in cold climate are larger and deeper with an extended detention time to remove pollutants with better removal efficiency. The minimum detention time for wetlands in cold climate is 10 to 13 days to ensure high quality effluent (Gustafson et. al. (2002)). Significant design considerations in cold climate areas are required for water storage during winter months, and inflow and outflow structures that withstand long periods of below frost temperatures, and high freeboard for year-round systems (Pries et. al. (1996), Eslamian et al., 2011).

There are opposing views on the presence or absence of temperature dependence in the BOD removal within treatment wetlands. To be stably removed from solution, organic nitrogen must be changed to ammonia $(\mathrm{NH} 4+)$, then oxidized to nitrite $(\mathrm{NO} 2-)$ and nitrate $\left(\mathrm{NO}^{-}\right)$, and finally denitrified to nitrogen gas (N2). Longer reaction times and various environmental conditions must be present to assimilate organic nitrogen in flow than a nitrate inflow. Nitrification and denitrification have all been indicated to be temperature dependent in wetlands during winter months. Therefore, the rate of total nitrogen removal depends on temperature. If oxygen transmission by diffusion and by plants through their aerenchym a and roots becomes in-sufficient to satisfy the carbonaceous oxygen demand during winter months, then the resulting anaerobic environment would avoid the nitrifying activity (Ham-mer and Knight, 1994). Nitrogen removal from wastewater is a complex process requiring a diverse microbial selective environment. Decreasing nitrogen removal efficiency during winter months may be due directly to temperature or it may be due to associated parameters, such as plant dormancy or reduced oxygen transport (Werker et. al.(2002),Eslamian et al., 2012, Eslamian et al., 2013, Eslamian et al., 2014,Eslamian et al., 2015).

\subsection{Literature Review}

Morari and Giardini (2009) investigated the treatment effect of two pilot-scale vertical flow constructed wetlands (VFCWs) on urban wastewaters and their feasibility of reusing for irrigation. 
Typhalatifolia and the phragmitesAustral were used for covering two VFCWs. The efficiency of these VFCWs was investigated in terms of mass removal and water quality improvement. In this study, the accumulation of factors in plant organs and VFCW sandy surface layer and their off take with macrophyte harvest were also evaluated. Higher removal efficiencies for COD, BOD, N and K were observed in quantitative terms, while the removal efficiency was lower for $\mathrm{Na}$ and $\mathrm{Mg}$. Because of the huge growth of macrophytes, these plants directly contribute to the removal of $\mathrm{N}, \mathrm{P}$ and $\mathrm{K}$. The results of water quality were less desirable because of high evapotranspiration losses. Higher concentrations were observed in outflow rather than inflow. At the end, the use of efficient precleaning systems or innovative integrated systems for decreasing the effect of ET on water quality was suggested to obtain high removal efficiencies (Ostad-Ali-Askari et al., 2016. Ostad-Ali-Askari et al., 2017, Eslamian et al., 2016, Eslamian et al., 2017).

In some studies, further treatment combining constructed wetlands and wastewater stabilization ponds for treated wastewater was done. Incorporating CWs with the original evaporation lagoons would not only increase wastewater quality but also store great amounts of water that could be used for other goals, such as irrigation (Zhang (2010)). Overall, wastewater treatment and agriculture reuse with the application of a CW-WSP system could be a practical wastewater management measure for protecting receiving water bodies and overcoming water shortages in decentralized rural areas (Ham et. al. (2007)).

Zhang (2010) and Ham, et al. (2007) applied combination of constructed wetland and wastewater stabilization pond for treated wastewater and its reuse in irrigation. In central Utah with hot dry summers and cold winters where the changes of normal mean temperature were from $20.9^{\circ} \mathrm{C}$ to $4.1^{\circ} \mathrm{C}$, Yue Zhang (2010) investigated the design and possibility of using free water surface constructed wetland system to treat the municipal wastewater. Results showed that after a relatively long retention time, the overall biochemical oxygen demands decreased by $93.6 \%$ to $97.8 \%$ and the total suspended solids decreased by $87.2 \%$ to $87.9 \%$. The treated water was adequate to irrigate approximately 45 acres of turf grass or 37 acres of pasture grass.

In a feasibility study, Ham, et al. (2007) investigated the performance of a constructed wetland (CWs) and wastewater stabilization pond (WSP) system for sewage reclamation and paddy rice irrigation in a decentralized rural area. These experimental CWs have been working steadily since 1997 in Seoul, Korea where the average ambient air temperature in the winter period for the study period was $-0.2^{\circ} \mathrm{C}$. The CWs had good removal efficiency, even in the winter period, but the effluent concentration was relatively large in the winter period. So a WSP was used for further treatment and the WSP effluent was introduced as safe for crop irrigation with respect to sewage-borne pathogens. Recycled water irrigation did not adversely affect the yield of rice, also this experiment showed an approximately $50 \%$ greater yield than in controls and the chemical characteristics of soil did not change considerably during the experimental period of irrigation with recycled water.

Moreno et al. (2007) evaluated the effectiveness of constructed and natural wetlands in removing nutrients from agricultural wastewater and their potential contribution to landscape heterogeneity in semiarid Mongers area, Northeast Spain., where the mean annual temperature was $14.5{ }^{\circ} \mathrm{C}$ and samples of water were collected at the inflow and outflow of the plots for two years. This study investigated how to neutralize the problems related to non-point pollution from irrigation of agricultural fields by constructed wetlands in a dry environment. The experimental wetlands showed significant $\mathrm{N}$ removal efficiency, despite being at the initial stages of their development. For phosphorus, the experimental wetlands ranged from exportation to removal of $80 \%$ of the phosphorus input. Results showed that the larger the wetland, the more removal efficiency was for N. Some differences between the first and second years of wetland operation were observed, meaning that these wetlands were progressing in their nutrient removal function towards advanced state with high nutrient removal efficiency as it was usual in similar wetlands.

Justin and Zupancic (2009) combined leachate pretreatment in a horizontal and vertical subsurface water flow constructed wetland (CWs), planted with phragmitesAustral is and subsequent reuse for irrigation of the closed and vegetated part of the landfill site. The mean temperature of leachate was at the inflow to $\mathrm{CWs}$ was $16.5^{\circ} \mathrm{C}$ between October and March, when mean air temperatures reached $3^{\circ} \mathrm{C}$. The retention of water peaks occurred due to contributed pre-treatment of leachate in CWs. Despite high concentrations of several pollutants and nutrients in pre-treated leachate, irrigation of 
vegetated landfill covers with high leachate input did not occur due to excessive accumulation of salts, heavy metals, or nutrients. The growth of plants on the irrigated landfill cover was better than the surrounding vegetation, because of further input of water and nutrients from the leachate.

Gross et al. (2007) developed a combination of vertical flow constructed wetland with a water recycling and trickling filter(RVFCW) that would provide safe and sustainable use of grey water for landscape irrigation in small communities and households. The treated grey water had no remarkable negative impact on plants or soil during the study period. In this study, the RVFCW was introduced as a sustainable and promising treatment system for grey water use that can be performed by unskilled operators.

In other area, the effect of temperature, hydraulic residence time (HRT), vegetation type, and porous media material and grain size on the performance of horizontal subsurface flow (HSF) constructed wetlands treating wastewater was investigated. During the operation period, four HRTs (i.e., 6, 8, 14 and 20 days) were used, while the wastewater temperature varied from about 2.0 to $26.0^{\circ} \mathrm{C}$. The removal efficiency of the constructed wetlands was obtained to be high and also showed a dependence on temperature. Results showed that an 8-day HRT was adequate for acceptable removal of organic matter, TKN and P-PO43-for temperatures above $15^{\circ} \mathrm{C}$. Also, based on statistical testing, cattails, finer media, and media obtained from a river indicated higher removal efficiencies of TKN and P$\mathrm{PO}^{3-}$ (Akratos and Tsihrintzis (2007), Eslamian et al., 2014).

Nivala et al. (2007) applied a pilot-scale subsurface-flow constructed wetland equipped with a patented wetland aeration process to aid the removal of organic matter and ammonia nitrogen to demonstrate the use of constructed wetlands as a possible low-cost treatment option for leachate generated at small landfills. Also, due to very cold air temperatures in winter in the study area, a layer of mulch insulation covered the top of the wetland bed to maintain the system from freezing. The high iron content of the leachate caused the aeration system to cease after 2 years into operation. Treatment efficiencies increased with the installation of a pretreatment chamber for iron removal and a new aeration system. Adequate insulation and aeration caused that these systems performed well, even during sub-freezing temperatures. Hence, high treatment efficiencies were observed with the installation of a pretreatment chamber for iron removal and a new aeration system.

Two free water surface (FWS) and two subsurface flow (SSF) pilot-size constructed wetlands were used for treating highway runoff (HRO) over a period of two years. A hydraulic retention time (HRT) of $12 \mathrm{~h}$ was considered for One FWS and one SSF, named FWS12 and SSF12, respectively, receiving a maximum HRO of $12.6 \mathrm{~m} 3 \mathrm{~d} 1$. The other couple, named FWS24 and SSF24, respectively, and an HRT for these was considered $24 \mathrm{~h}$, each receiving a maximum HRO of $6.3 \mathrm{~m}^{3} \mathrm{~d}^{-1}$. The performance among the four sets of experiments was not remarkably different according to ANOVA analysis for almost all the measured physicochemical parameters, so it was suggested that all systems performed in a similar way; A mean of two-year removal efficiencies for all studied systems was almost the same for each of the parameters(Terzakis a,b et al(2008)).

The effect of climate, season, and wastewater quality on pollutant removal efficiency of constructed wetlands in Mediterranean and Continental-Mediterranean climate region of Spain was investigated by Marianna Garfía et al (2012). To this end, two experimental horizontal subsurface flow constructed wetlands were implemented. Phragmitesaustral is planted in both constructed wetlands. Total suspended solids, biochemical oxygen demand, and ammonium mass removal efficiencies showed a dependence on season, with higher amounts in summer rather than in winter. Results of this work showed that horizontal subsurface flow constructed wetland was a successful technology for both regions considered, even if winter appeared to be a critical period for ammonium removal in continental climate regions (Marianna Garfía et al (2012)).

In northern Japan, another cold climate area, the performance of six multi-stage hybrid wetland systems was investigated. The systems were designed to treat four kinds of wastewater: dairy wastewater, wastewater from a pig farm, including liquid food washing wastewater, wastewater from potato starch processing, and wastewater containing pig farm swine urine. These systems combined three to four vertical (V) flow beds with self-priming siphons and surface partitions and no or one horizontal( $\mathrm{H})$ flow bed (total of three to five beds). In order to avoid clogging and frost and maintain dry conditions and plentiful growth of reeds and earthworms, the safety bypass structure and floating cover material were used. The mean treated rates were $70-96 \%$ for chemical oxygen demand 
(COD), 39-90\% for total nitrogen (TN), 36-82\% for $\mathrm{NH} 4-\mathrm{N}$, and $70-93 \%$ for total phosphorous (TP). The estimated mean oxygen transfers rates (OTRs) were 16-99 g O2 m-2d-1. By treating higher organic loads per area without clogging, it was possible to minimize the area and cost of treating high-content wastewater. At the end, it was suggested that more information was obtained concerning load and OTR to design a more efficient multi-stage wetland system. (Kato et al (2013))

Bulk (2006) used a constructed wetland (CW) as a pilot integrated system consisting of three interconnected beds, two of vertical flow and one of horizontal flow stage for the capital city's old sanitary landfill site. The efficiency of the CW system was investigated for 7 years using physical and chemical parameters. The implementation of the system did not change considerably with regard to temperature; however, it changed with precipitation. Results indicated that the $\mathrm{CW}$ system, as a tertiary system or as an independent system, could be a low-cost alternative for the treatment of leachate from old landfill sites.

The present study discusses the results of wetlands in cold and moderate regions of the world. The goal here is to investigate the feasibility of using effluent constructed wetlands for irrigation. Also it provides models for estimating the effluent of these wetlands with influent.

\section{FEASIBILITY AND MODELING}

Although irrigation has been done worldwide for several thousand years, the importance of quality of irrigation water has been emphasized only in the last century. The feasibility of irrigation with water treated by constructed wetlands was investigated, based on several parameters in various studies in different areas of world with cold and moderate climate, that contain nutrient levels; BOD5, biological oxygen demand over a 5-day period; COD, chemical oxygen demand; TSS, total suspended solids; T-P, total phosphorus; T-N, total nitrogen; NH4, ammonium; EC, electric conductivity, and FC; Fecal coliform (Shayannejad et al., 2017.,

Electrical conductivity (EC) is the most convenient way of measuring water salinity. The salinity of studied system effluent was in the range of 0.237-2.12 dS/m. Based on the Food and Agriculture Organization (FAO) irrigation water quality guidelines (FAO, 1985), the degree of reuse restriction for these effluents was insignificant to moderate $(0.7-3.0 \mathrm{dS} / \mathrm{m})$ for irrigation crops.

The presence of nutrients in treated wastewater can provide a fertilizer value for crop production. Nitrogen is the most useful nutrient that often exists in high concentrations in reclaimed wastewater. However, excessive nitrogen causes increased vegetative growth, delayed or uneven maturity, reduced crop quality, and may be injurious to many crops. The average nitrate (NO3) concentration of the studied constructed wetland effluent was $22 \mathrm{mg} / \mathrm{L}$. According to the guidelines for interpretation of water quality for irrigation (Ayres and Westcott, 1976) more than $5 \mathrm{mg} / \mathrm{L}$ is considered no problem, almost $51.28 \%$ investigated effluents are classified as no problem and $15.38 \%$ of these create severe problems. However, because the reclaimed irrigation water may be mixed with about precipitation water, a volume about two or three times greater than that of the irrigation water during the irrigation season in some areas. Classification of NO3 effluent concentration according to Ayres and Westcott (1976) is shown in figure 1.
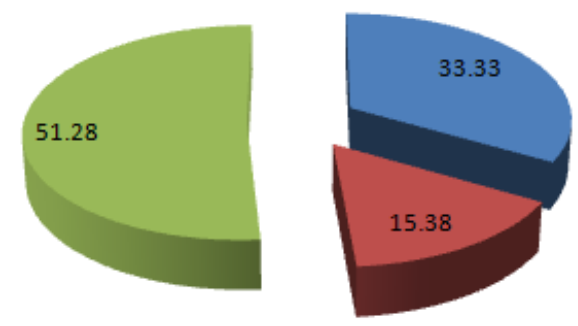

$$
\begin{aligned}
& \text { IncreasingProblem } \\
& \text { severe problem } \\
& \text { no problem }
\end{aligned}
$$

Figure1: Classification NO3 effluent concentration according to Ayres and Westcott (1976)

To reuse the WSP effluent as crop irrigation water, blending the WSP effluent with other irrigation water keeps salinity under control $(0.7 \mathrm{dS} / \mathrm{m})$, and its supplemental use is therefore recommended. 
The CW studied by Ham et al. (2007) and Nivala et al. (2007) showed that in summer and the growing season, higher temperatures caused the increase of wetland performance for wastewater contaminant removal. Hence, to decrease effluent levels in the study wetlands, it is suggested that this system is operated in summer and the season growing for cold climate areas.

As seen in Table 2, more than half of the influent concentration of BOD5 was removed in the study constructed wetlands. This table shows that the BOD5 removal rates were high. The correlation was significant at the level 0.01 between mean removal efficiency and influent concentration of BOD5 but the correlation coefficient was low and this was equal to 0.23. Ran et al. (2004) showed that the organic removal rates were high and increased linearly with organic and hydraulic load. This study was conducted in warm climate. The correlation coefficient between effluent and influent concentrations of BOD5 was not significant and the regression coefficient was poor. The data was divided into three zones and all these zones had strong regression.

Table2: Removal efficiency of study $C W s$

\begin{tabular}{|l|l|}
\hline \multicolumn{1}{|c|}{ Area } & \\
\hline Slovenia & 65.80 \\
\hline Padova, Italy & 59.31 \\
\hline Padova, Italy & 61.11 \\
\hline Padova, Italy & 93.78 \\
\hline Padova, Italy & 92.17 \\
\hline Ben-Gurion, Israel & 99.85 \\
\hline Indiana, USA & 98.41 \\
\hline Greece & 88.59 \\
\hline Greece & 85.07 \\
\hline Greece & 86.13 \\
\hline Greece & 89.26 \\
\hline Greece & 87.48 \\
\hline Iowa ,USA & 87.63 \\
\hline Iowa,USA & 95.45 \\
\hline Iowa,USA & 96.89 \\
\hline Iowa ,USA & 88.54 \\
\hline Iowa, USA & 80.84 \\
\hline Iowa,USA & 78.95 \\
\hline Iowa ,USA & 75.29 \\
\hline Iowa,USA & 75.28 \\
\hline Seol, Korea & 82.06 \\
\hline Seol, Korea & 58.78 \\
\hline Barcelona, Spain & 89.67 \\
\hline Leon, Spain & 64.55 \\
\hline Slovenia & 63.16 \\
\hline Negev, Israel & 71.58 \\
\hline
\end{tabular}

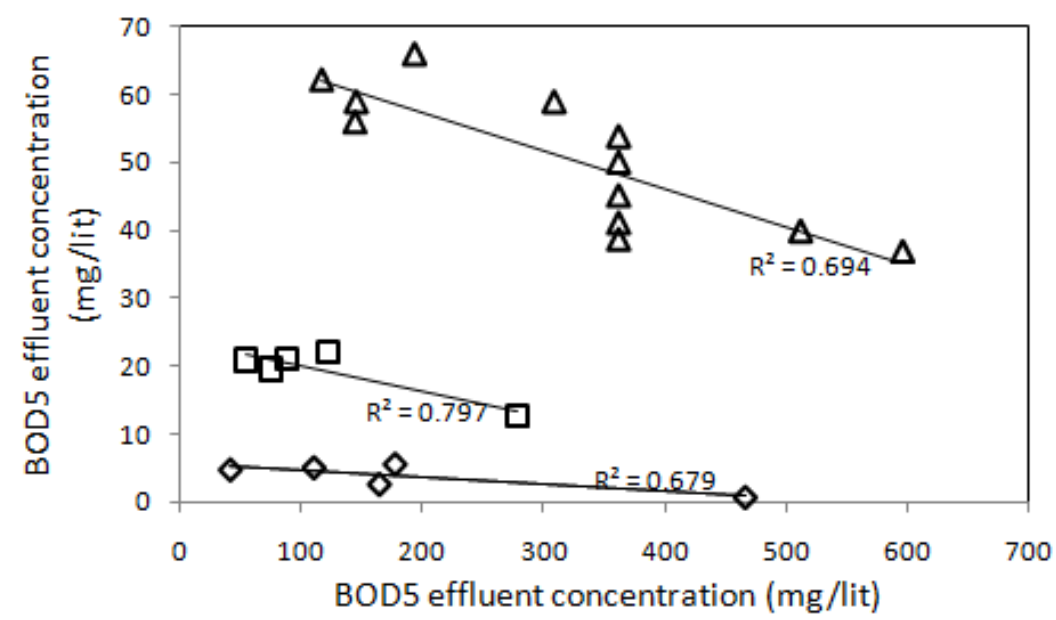

Figure2: Correlation between BOD5 effluent and removal efficiency 
In 14 out of 39 cases, the concentration of BOD5 in the effluent of wetland was more than $30 \mathrm{mg} \mathrm{O} / \mathrm{l}$ and therefore these cases were not appropriate for reuse according to the U.S. EPA guidelines (U.S. EPA, 2012). In 12 cases, the concentration is included between $10 \mathrm{mg} \mathrm{O} / 1$ and $30 \mathrm{mg} \mathrm{O}_{2} / \mathrm{l}$; according to the U.S. EPA guidelines this reclaimed water was suitable for irrigation in restricted access areas, for irrigation of crops which are not consumed by humans including fodder, fiber, and seed crops, or to irrigate pasture land, commercial nurseries, and sod farms and food crops which are intended for human consumption, commercially processed. In the other 13 cases, the effluent concentration was lower than $10 \mathrm{mg} \mathrm{O}_{2} / 1$ and therefore also suitable for surface or spray irrigation of food crops which are intended for human consumption, as consumed raw (U.S. EPA, 2012).

Investigated wetlands showed a remarkable BOD5 removal efficiency (58.8-99.84\% of the influent BOD5 concentration), in spite of the fact that only $62 \%$ of these were according to the U.S. EPA guidelines.

The maximum removal efficiency of BOD5 was obtained when grey water for landscape irrigation was used as wastewater in constructed wetland. Also small landfills treated by these systems had high efficiency and low influent concentration, hence constructed wetland effluent was appropriate (according to the U.S. EPA guidelines).

Overall, wastewater treatment and agronomic reuse using a CW-WSP system or aerated subsurfaceflow constructed wetland could be a practical integrated wastewater management measure for protecting receiving water bodies and overcoming water shortages.

Aerated subsurface-flow constructed wetlands were presented as a viable low-cost treatment alternative for the treatment of landfill leachate by Nivala et al. (2007). This system can be implemented even during subfreezing temperatures if it is insulated and aerated enough.

The correlation between TSS influent and effluent was significant at the 0.01 level and followed an equation as $\mathrm{y}=0.359 \mathrm{x}-21.58$. This correlation is shown in figure 4 . The regression coefficient of this correlation was very strong and equal to 0.87 .

The mean removal of TSS in the investigated wetlands was $51.18 \%$ (in same study). This value was lower than the removal of BOD5. The Removal efficiency for BOD5 and TSS in the investigated wetlands was compared in Figure 5 which shows that the removal efficiency BOD5 was more than the removal efficiency of TSS in most cases.

The average TSS concentrations of influent and effluent were 277.5 and $79.7 \mathrm{mg} / \mathrm{l}$, respectively. Hence, it can be concluded that many wetlands actually work as sources of suspended solids. In most cases, the concentration of TSS in the wetland effluent was less than $30 \mathrm{mg} \mathrm{O}_{2} / 1$ and therefore wetlands were able to remove this parameter, based on the U.S. EPA guidelines for reuse (U.S. EPA, 2012). In $25 \%$ of cases, the effluent concentration was high and good removal efficiency could be due to high influent concentration. Also, the suspended solids in the effluent of CWs were of a different nature than those in conventionally treated wastewater. While the effluent of activated sludge systems largely included sludge flocks, the effluent from the wetland included mostly algae and small organisms (Kampf and Claassen (2004), Shayannejad et al., 2015. Eslamian et al., 2017., Eslamian et al., Godarzi et al.,2017., Shojaei et al., 2017., Sayedipour et al., 2017. Eskandari et al., 2017, Chavoshi-Boroujeni et al., 1999, Feyzi et al., 2005).

Results indicated that constructed wetlands in cold and moderate climate helped the removal of TSS up to a level that reflected their background concentration and were compatible with the quality standards for most reuse application in irrigation of most crops.

Investigation of constructed wetlands in several areas with cold climate showed that using domestic and municipal wastewater did not create appropriate TSS effluent concentration due to both low removal efficiency and high influent concentration, so treated domestic and municipal wastewater by $\mathrm{CW}$ was not recommended for irrigation, unless combined methods were used for further polishing of constructed wetland effluent. 


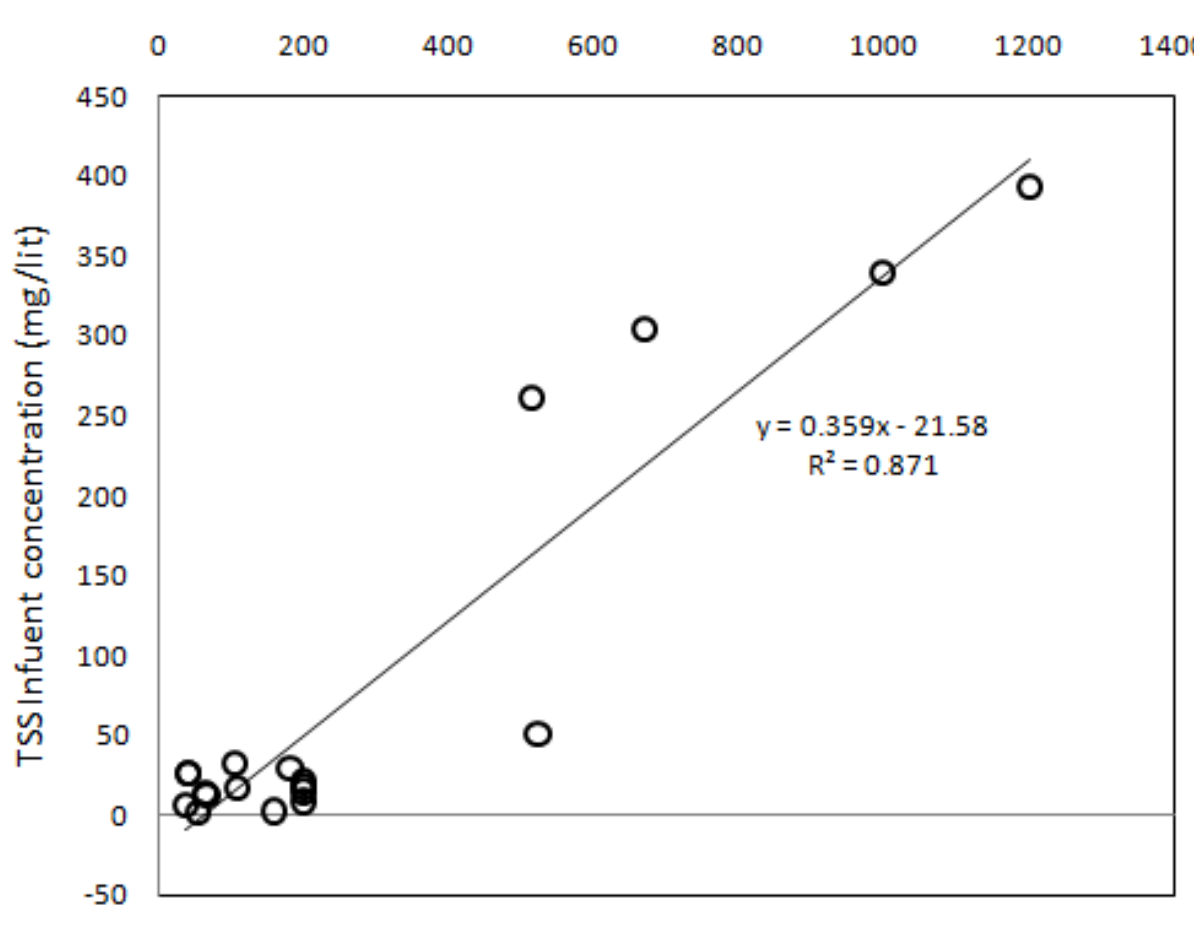

TSS Infuent concentration ( $\mathrm{mg} / \mathrm{lit}$ )

Figure4: Correlation between TSS influent and effluent concentrations

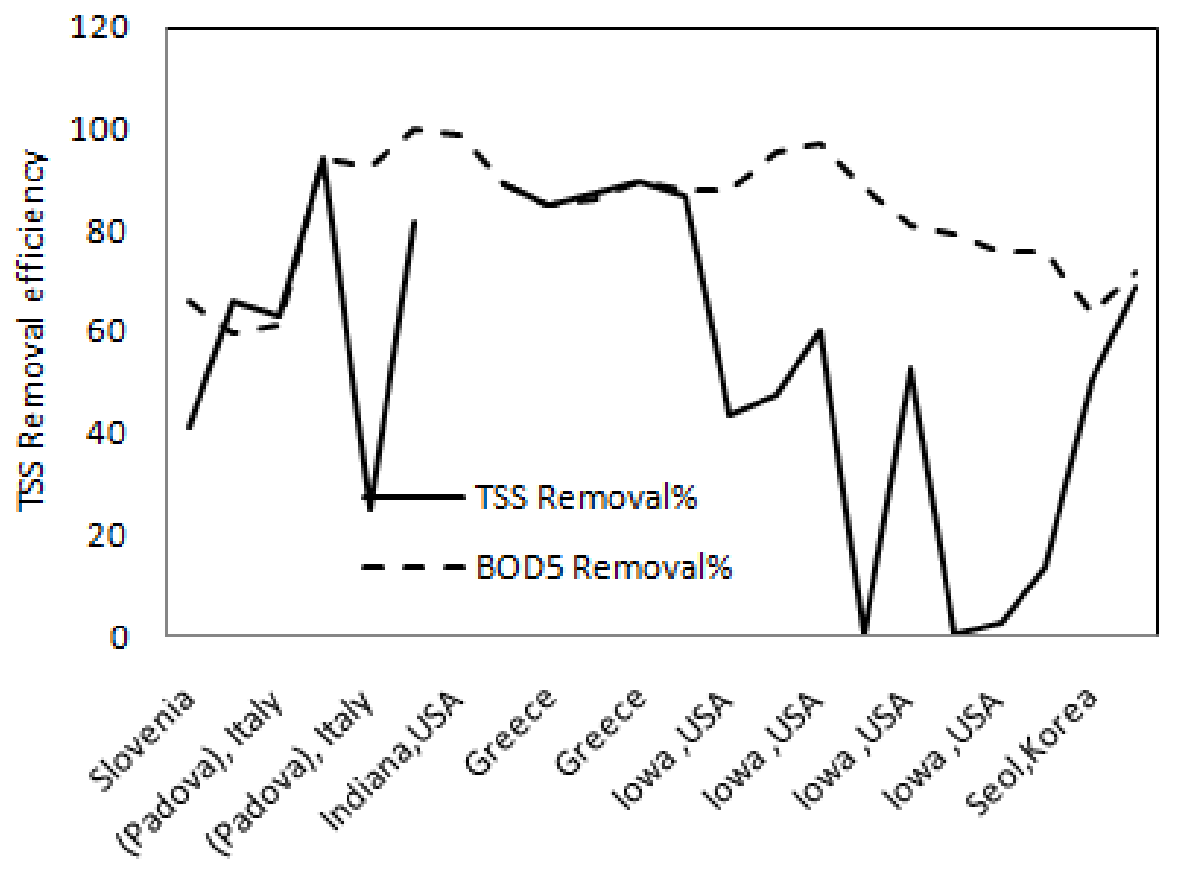

Figure5: Removal efficiency for BOD5 and TSS in investigated wetlands

Table 5 summarizes the findings concerning the removal of FC in the investigated systems. Faucal coliforms (FC) are by far the most commonly used indicator of pathogenic contamination that has been monitored in tertiary FWS wetlands (Ghermandi et al., 2006, Shayannejad et al., 2016., OstadAli-Askari et al., 2015), but few studies have reported this parameter. Removal percentages in figure 6 show that $\mathrm{CW}$ is able to remove $\mathrm{FC}$ even up to $99 \%$. In spite of high removal efficiency in all wetlands, only in one case out of six cases, the FC concentration effluent was appropriate for irrigation according to the U.S. EPA guidelines (U.S. EPA, 2012). In 3 out of 6cases there was improvement, according to the quality standards set by NWQMS (1996) for landscape irrigation, irrigation of pasture and fodder,horticulture, irrigation of food crops not in direct contact with water or sold to consumers cooked or processed. Inadequate concentration in effluent was because of too high concentration. 
Table3: Influent and effluent concentrations of FC and removal efficiency

\begin{tabular}{|l|l|l|l|}
\hline Area & Influent & Effluent & Removal Efficiency\% \\
\hline Slovenia & 50000000 & 440 & 99.99 \\
\hline Ben-Gurion, Israel & 50000000 & 200000 & 99.6 \\
\hline Seol, Korea & 693800 & 7667 & 98.89 \\
\hline Seol, Korea & 564910 & 5256 & 99.06 \\
\hline Seol, Korea & 7883.3 & 431.7 & 94.52 \\
\hline Negev, Israel & 838500 & 76500 & 90.87 \\
\hline
\end{tabular}

Also based on the World Health Organization (WHO) microbiological guidelines for treated wastewater (WHO, 1989, 2000), FC counts should be less than 1,000 MPN/ $100 \mathrm{~mL}$ for irrigation of crops for human consumption. In this investigation, in four cases the FC effluent from study systems was still too high for reuse as irrigation water.

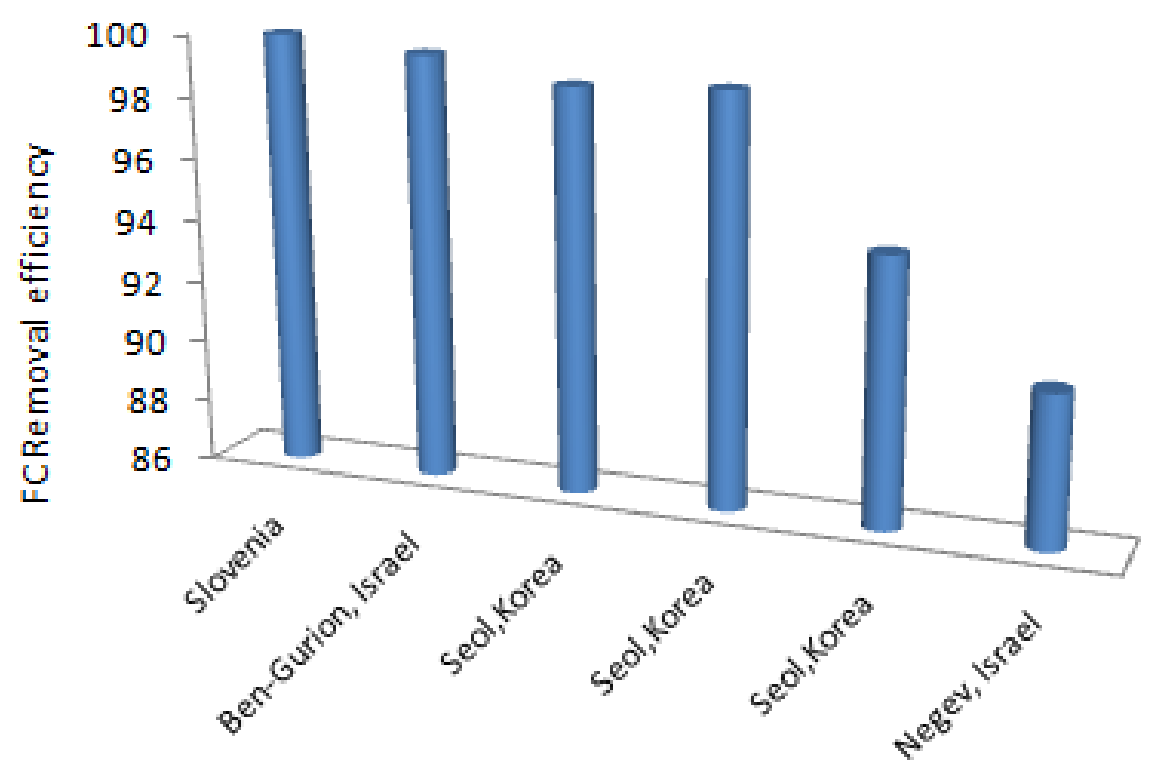

Figure6: Removal efficiency for FC in investigated wetlands

Figure7 shows that the acidity of effluent from study systems was in the range of 6-9 according to US EPA guidelines. So this effluent from CWs in cold climate was appropriate for irrigation of all crops. CWs did not have a significant effect on PH parameters and didn't change outside of the standard range. Also there was a significant correlation between $\mathrm{pH}$ influent and effluent. This correlation was a polynomial of second degrees $y=-1.863 x^{2}+26.19 x-84.27$. Figure 8 shows the correlation of between $\mathrm{pH}$ of wastewater influent and of effluent.

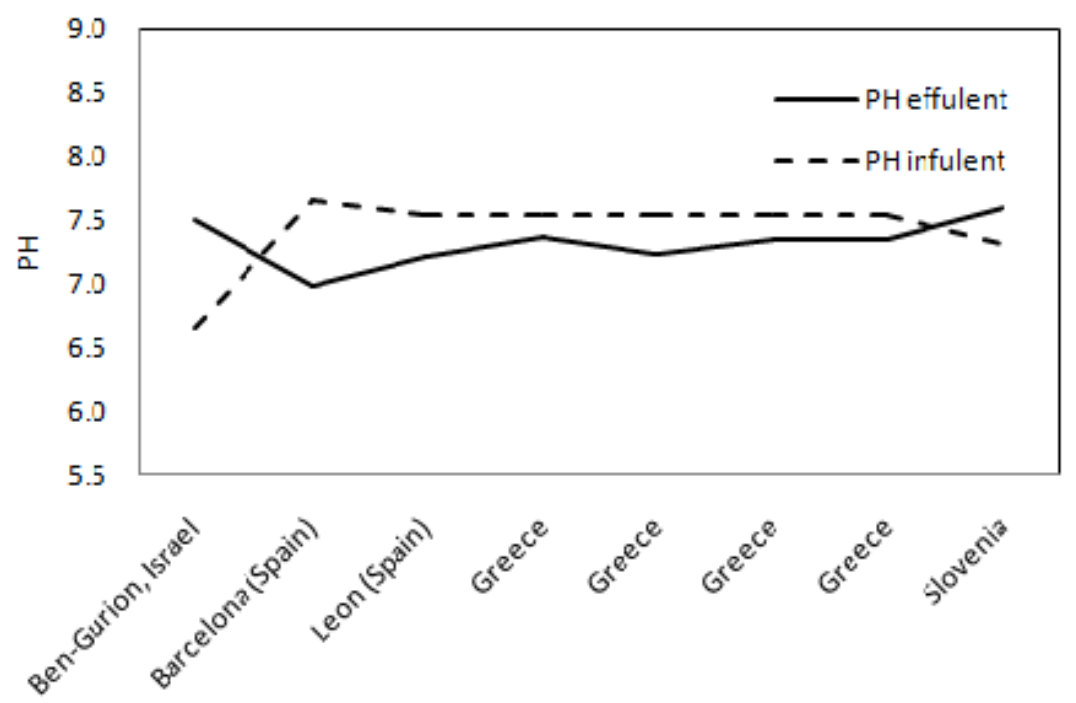

Figure7: Acidity of influent and effluent constructed wetlands 


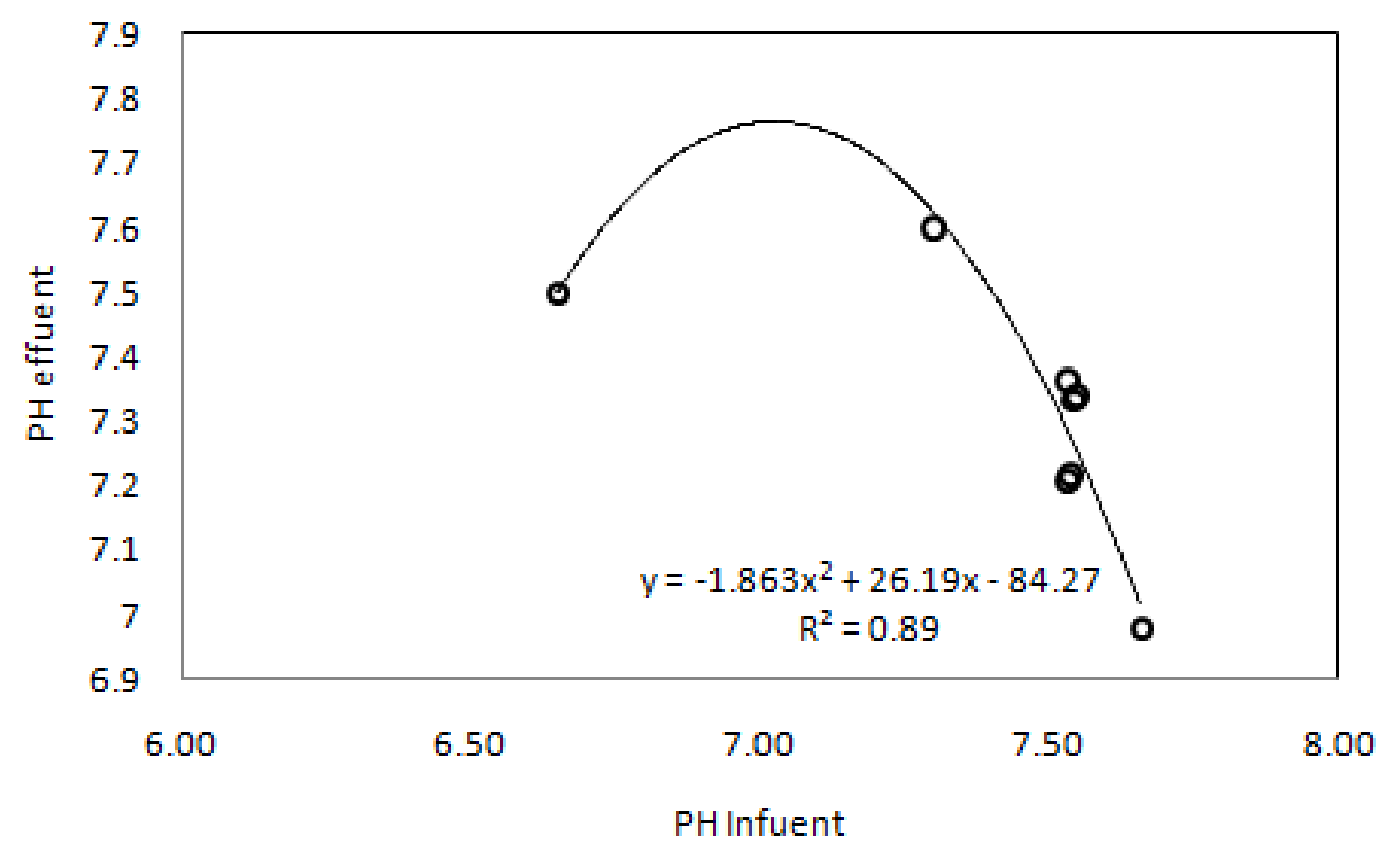

Figure8: Correlation of between pH of influent and of effluent

\section{CONCLUSION}

By means of an extensive investigation of relevant studies on tertiary constructed wetlands in cold climate worldwide, the following conclusions can be drawn from this study:

Investigated wetlands showed a remarkable BOD5 removal efficiency (58.8-99.84\% of the influent BOD5 concentration), in spite of the fact that only $62 \%$ of these were according to the US EPA guidelines.

Constructed wetlands in cold and moderate climate can help the removal of TSS up to a level that reflects their background concentration which is compatible with the quality standards for most reuse application in irrigation of most crops, but in $25 \%$ of the cases, the effluent isn't suitable for all reuse applications in irrigation for which a threshold on the concentration of TSS is foreseen in the U.S. EPA guidelines. The removal efficiency of BOD5 is more than the removal efficiency TSS in most cases.

Constructed wetlands cannot provide a water reclamation solution from the viewpoint of microbiological quality that can meet reuse quality standards for irrigation. The microbiological quality of the water is improved but still it isn't appropriate for irrigation according to the U.S. EPA. Also, based on the World Health Organization (WHO) the four cases of FC effluent from study systems were still too high for reuse as irrigation water.

The acidity of effluent from the study systems is the range of 6-9 according to U.S. EPA guidelines. So this effluent from constructed wetlands in cold climate is appropriate for irrigation all crops.

For reusing constructed wetlands effluent in irrigation, combined systems like WSP-CW system require complying with the standard effluent of reuse water.

\section{REFERENCES}

[1] 43. Cooper, P.F.; Job, G.D.; Green, M.B.; Shutes, R.B.E. Reed Beds and Constructed Wetlands for Wastewater Treatment; WRc Publications: Medmenham, UK, 1996.

[2] Abedi-Koupai, J., Eslamian, S. S. and Fakouri, F., 2010, The Effects of Applying Treated Wastewater on the Physical and Mechanical Behavior of Soil-Root Interactions, Geophysical Research Abstracts, Vol. 12, EGU2010-13610, EGU General Assembly, Vienna, Austria.

[3] Abedi-Koupai, J., Ghaheri, E., Eslamian, S.S. and Hosseini, H., 2013, Investigation the Kinetic Models of Biological Removal of Petroleum Contaminated Soil around Oil Pipeline Using Ryegrass, Water and Wastewater, Vol. 89, No. 1, 62-68.

[4] Abedi-koupai, J., Mollaei, R., Eslamian, S. S., 2015, the effect of pumice on reduction of cadmium uptake by spinach irrigated with wastewater, Ecohydrology and Hydrobiology, Vol. 15, No. 4, 208-214. 
[5] Akratos, C. S., \& Tsihrintzis, V. A. (2007). Effect of temperature, HRT, vegetation and porous media on removal efficiency of pilot-scale horizontal subsurface flow constructed wetlands. Ecological Engineering, 29(2), 173-191.

[6] Amininejad, S. M., Eslamian, S. S., Amininezhad, S. M., 2013, Application of ZnO Nanoparticles in Wastewater Disinfection, 5th International conference of Water Resources and Sustainable Development, 24-25 February, Algiers.

[7] Amininejad, S. M., Eslamian, S. S., Amininezhad, S. M., 2013, Photo catalytic Degradation of Model Textile Dyes in Wastewater Using ZnO Nanoparticles, 5th International Conference of Water Resources and Sustainable Development, 24-25 February, Algiers.

[8] Amiri, M. J., Abedi-Koupai, J., Eslamian, S., Mousavi, S. F. and Arshadi, M., 2013, Modeling Pb(II) adsorption based on synthetic and industrial wastewaters by ostrich bone char using artificial neural network and multivariate non-linear regression, Int. J. Hydrology Science and Technology, Vol. 3, No. 3, 221-240.

[9] Bahmanpour H, Awhadi S, Enjili J, Hosseini S.M, RaeisiVanani H, Eslamian S, Ostad-Ali-Askari K. 2017, Optimizing Absorbent Bentonite and Evaluation of Contaminants Removal from Petrochemical Industries Wastewater. International Journal of Constructive Research in Civil Engineering (IJCRCE), 3(2): 34-42.

[10] Boogaard, F. and Eslamian, S , 2015, Wastewater Monitoring, Urban Water Reuse Handbook, Ch. 48, Ed. By Eslamian, S., Taylor and Francis, CRC Group, 583-586.

[11] Brix, H.; Schierup, H.-H. The use of macrophytes in water pollution control. AMBIO 1989, 18, 100-107.

[12] Bulc, T. G. (2006). Long term performance of a constructed wetland for landfill leachate treatment. Ecological Engineering, 26(4), 365-374.

[13] Chavoshi, S. and S. Eslamian, 2001, The role of traditional utilization of water in management of water resources of arid land, Second Regional Conference on Water and Wastewater Management in Asia, Tehran, Iran.

[14] Chavoshi-Boroujeni, S. and S. Eslamian, 1999, Regional Flood Analysis in Arid Zones Using Hybrid Method, Water and Wastewater Journal, Vol. 30: 23-35.

[15] Crusberg, T. C., and Eslamian, S., 2015, Choosing Indicators of Fecal Pollution for Wastewater Reuse Opportunities, Urban Water Reuse Handbook, Ch. 42, Ed. By Eslamian, S., Taylor and Francis, CRC Group, 511-520.

[16] David, M. G., James, L. A., Christopherson, S. H., \&Axler, R. (2002). A report of constructed wetlands. Minneapolis, MN: University of Minnesota.

[17] DehghanSh, Kamaneh S.A.A., Eslamian S, Gandomkar A, Marani-Barzani M, Amoushahi-Khouzani M, Singh V.P., Ostad-Ali-Askari K. 2017, Changes in Temperature and Precipitation with the Analysis of Geomorphic Basin Chaos in Shiraz, Iran. International Journal of Constructive Research in Civil Engineering (IJCRCE), 3(2): 50-57.

[18] Environmental Protection Agency (U.S. EPA). (1999). U.S. EPA manual: constructed wetlands treatment of municipal wastewaters (EPA/625/R-99/010). Cincinnati, OH: National Risk Management Research Laboratory, Office of Research and Development.

[19] Eskandari S, Hoodaji M, Tahmourespour A, Abdollahi A, Mohammadian-Baghi T, Eslamian S, Ostad-AliAskari K. 2017, Bioremediation of Polycyclic Aromatic Hydrocarbons by Bacillus Licheniformis ATHE9 and Bacillus Mojavensis ATHE13 as Newly Strains Isolated from Oil-Contaminated Soil. Journal of Geography, Environment and Earth Science International, 11(2): 1-11.

[20] Eslamian S, Mirabbasi-Najafabadi R, Ostad-Ali-Askari K. Advance Engineering Statistics (Simulation and Modeling of Uncertainty and Sensitivity Analysis). Kankash Publisher. First Edition, 2017. ISBN: 978600-136-359-7. Isfahan, Iran.

[21] Eslamian S, Ostad-Ali-Askari K, Soltani M. 2017, Climate Variability: Integration of Renewable Energy into Present and Future Energy Systems in Designing Residential Buildings. International journal of Rural Development, Environment and Health Research (IJREH), 1(2): 18-30.

[22] Eslamian, S. and Tarkesh-Isfahani, S., 2010. Evaluating the most efficient irrigation systems in wastewater reuse, Pakistan Agriculture: Challenges and Opportunities, Kashmir, Pakistan.

[23] Eslamian, S. S. and K. Farzamnia, 1999, Regionalization of Flood Frequency Estimation using Cluster Analysis, Water and Wastewater Journal, Vol. 31: 1-12.

[24] Eslamian, S. S., Hedayat, E. and S. TarkeshEsfahani, 2009, Reusing Reclaimed Wastewater through Artificial Recharge for Increasing Sustainable Water, First Conference of Water Resources Management, Shahroud, Iran. 
[25] Eslamian, S. S., Modarres, R. and S. Soltani, 2006, Spatial Grouping of Drought Using Standardized Precipitation Index in Isfahan Province, Water and Wastewater Journal, No. 57, 72-75.

[26] Eslamian, S. S., Tarkesh-Isfahany, S., 2011, Industrial reuse of urban wastewaters, a step towards sustainable development of water resources, 1st International Conference on Desalination and Environment: A Water Summit, 29 Oct. 1 Nov., Beach Rotana, Abu Dhabi, and UAE.

[27] Eslamian, S., Tarkesh-Isfahani, S., Malekpour, I., 2010, investigating heavy metals concentration of a wastewater treatment plant for agricultural and landscape reuses, Dryland Hydrology: Global Challenges Local Solutions, September 1-4, Westin La Paloma-Tucson, USA.

[28] Fazlolahi, H. and S. S. Eslamian, 2013, Nitrogen and Phosphorus removal from municipal wastewater by three wetland plant species, Journal of River Engineering, Vol. 1, No. 2. 14-20.

[29] Fazlolahi, H. and S. S. Eslamian, 2014, Using wetland plants in nutrient removal from municipal wastewater, Int. J. Hydrology Science and Technology, Vol. 4, No. 1, 68-80.

[30] Feyzi, H. and S. S. Eslamian, 2005, Comparing regional and at-site L-moments for estimation of maximum monthly rainfall in the Zayandehroud basin, Water and Wastewater Journal, Vol. 53, 1-13. From http://www.extension.umn.edu/distribution/naturalresources/DD7671.html

[31] Garfí, M., Pedescoll, A., Bécares, E., Hijosa-Valsero, M., Sidrach-Cardona, R., \&García, J. (2012). Effect of climatic conditions, season and wastewater quality on contaminant removal efficiency of two experimental constructed wetlands in different regions of Spain. Science of the Total Environment, 437, 61-67.

[32] Godarzi A, Eslamian S, Ostad-Ali-Askari K. Water in Literature Aspects (Social and Cultural Aspects). Publication of Tehran Municipality. First Edition, 2016. ISBN: 978-600-439-096-5. Tehran, Iran.

[33] Gottschall, N., Boutin, C., Crolla, A., Kinsley, C., \& Champagne, P. (2007). The role of plants in the removal of nutrients at a constructed wetland treating agricultural (dairy) wastewater, Ontario, Canada. Ecological Engineering, 29(2), 154-163.

[34] Gross, A., Shmueli, O., Ronen, Z., \&Raveh, E. 2007. Recycled vertical flow constructed wetland (RVFCW) - a novel method of recycling greywater for irrigation in small communities and households. Chemosphere, 66(5), 916-923.

[35] Gustafson, M. D., Anderson, J. L., Christopherson, S. H., \& Alex, R. (2002). Innovative onsite sewage treatment systems webpage. Farmington, MN: University of Minnesota Extension Service. Retrieved April 10,2012 ,

[36] Ham, J., Yoon, C., Jeon, J., \& Kim, H. (2007). Feasibility of a constructed wetland and wastewater stabilisation pond system as a sewage reclamation system for agricultural reuse in a decentralised rural area. Water Science \& Technology, 55(1-2), 503-511.

[37] Hamdy, A. and Eslamian, S., 2015, Sustainable Reuse and Recycling of Treated Urban Wastewater, Urban Water Reuse Handbook, Ch. 80, Ed. By Eslamian, S., Taylor and Francis, CRC Group, 1039-1054.

[38] Hammer, D. A., \& Knight, R. L. (1994). Designing constructed wetlands for nitrogen removal. Water Science \& Technology, 29(4), 15-27.

[39] Justin, M. Z., \& Zupančič, M. (2009). Combined purification and reuse of landfill leachate by constructed wetland and irrigation of grass and willows. Desalination, 246(1), 157-168.

[40] Kadlec, R. H., \& Knight, R. L. (1996). Treatment wetlands. Boca Raton, FL: CRC Press.

[41] Kadlec, R. H., \& Tilton, D. L. (1979). The use of freshwater wetlands as a tertiary wastewater treatment alternative. CRC Critical Reviews in Environmental Control, 9, 185-212.

[42] Kadlec, R. H., Richardson, C. J., \&Kadlec, J. A. (1975). The effects of sewage effluent on wetland ecosystems (Semi-Annual Report No. 4). Ann Arbor, MI: University of Michigan. (NTIS PB 2429192).

[43] Kadlec, R.H.; Wallace, S.D. Treatment Wetlands, 2nd ed.; CRC Press: Boca Raton, FL, USA, 2008.

[44] Maehlum, T., Jenssen, P. D., \& Warner, W. S. (1995). Cold-climate constructed wetlands. Water Science and Technology, 32(3), 95-101.

[45] Morari, F., \& Giardini, L. 2009. Municipal wastewater treatment with vertical flow constructed wetlands for irrigation reuse. Ecological Engineering, 35(5), 643-653.

[46] Moreno, D., Pedrocchi, C., Comín, F. A., García, M., \&Cabezas, A. 2007. Creating wetlands for the improvement of water quality and landscape restoration in semi-arid zones degraded by intensive agricultural use. Ecological engineering, 30(2), 103-111.

[47] Moreno, D., Pedrocchi, C., Comín, F. A., García, M., \&Cabezas, A. (2007). Creating wetlands for the improvement of water quality and landscape restoration in semi-arid zones degraded by intensive agricultural use. Ecological engineering, 30(2), 103-111. 
[48] Moreno, D., Pedrocchi, C., Comín, F. A., García, M., \&Cabezas, A. (2007). Creating wetlands for the improvement of water quality and landscape restoration in semi-arid zones degraded by intensive agricultural use. Ecological engineering, 30(2), 103-111.

[49] Mousavi, S. Z., Eslamian, S. S., Sharifani, M., 2010, Increasing Berhi Date Palm's Yield and Cost Efficiency, as Irrigated by Reclaimed Sewage Wastewater, Pakistan Agriculture: Challenges and Opportunities, Kashmir, Pakistan

[50] Nivala, J., Hoos, M. B., Cross, C., Wallace, S., \&Parkin, G. 2007. Treatment of landfill leachate using an aerated, horizontal subsurface-flow constructed wetland. Science of the Total Environment, 380(1), 19-27.

[51] Odum, H. T., Ewel, K. C., Mitsch, W. J., \& Ordway, J. W. (1977). Recycling treated sewage through cypress wetlands in Florida. In F. M. D'Itri (Ed.), Wastewater renovation and reuse (pp. 35-67). New York, NY: Marcel Dekker.

[52] Organization of American States (1997). Source book of alternative technologies for freshwater augmentation in Latin America and the Caribbean. Washington, DC: Unit of Sustainable Development and Environment General Secretariat, OAS Department of Sustainable Development.

[53] Ostad-Ali- Askari, K., Shayannejad, M. 2015, The effect of heterogeneity due to inappropriate tillage on water advance and recession in furrow irrigation. Journal of Agricultural Science, 7(6), 127-136.

[54] Ostad-Ali-Askari K, Eslamian S, Shayannejad M, et al. Groundwater Hydrodynamic. Horoufchin Publisher. First Edition, 2016. ISBN: 978-600-7419-53-3. Isfahan, Iran.

[55] Ostad-Ali-Askari K, Shayannejad M, Eslamian S, et al. 2017, Deficit Irrigation: Optimization Models. Management of Drought and Water Scarcity. Handbook of Drought and Water Scarcity, Taylor \& Francis Publisher, USA. Vol. 3. $1^{\text {th }}$ Edition, pp: 373-389.

[56] Ostad-Ali-Askari K, Shayannejad M, Eslamian S, Jahangiri A.K, Shabani A.H, Environmental Hydraulics of Open Channel Flows. Kankash Publisher. First Edition, 2015. ISBN: 978-600-136-303-0.

[57] Ostad-Ali-Askari K, Shayannejad M, Eslamian S, Navab-Pour B. 2016, Comparison of solution of SaintVenant equations by characteristics and finite difference methods for unsteady flow analyzing in open channel. International Journal of Hydrology Science and Technology, 6(3), 9-18.

[58] Ostad-Ali-Askari K, Shayannejad M, Ghorbanizadeh-Kharazi H. 2017, Artificial Neural Network for Modeling Nitrate Pollution of Groundwater in Marginal Area of Zayandeh-rood River, Isfahan, Iran. KSCE Journal of Civil Engineering, 21(1):134-140. Korean Society of Civil Engineers. DOI $10.1007 / \mathrm{s} 12205-016-0572-8$.

[59] Ostad-Ali-Askari K, Shayannejad M, Golabchian M. Numerical methods in groundwater. Kankash publisher. First edition, 2015. ISBN: 978-600-136-276-7. Isfahan, Iran.

[60] Ostad-Ali-Askari K, Shayannejad M. 2016, FLOOD ROUTING IN RIVERS BY MUSKINGUM'S METHOD WITH NEW ADJUSTED COEFFICIENTS. International Water Technology Journal, IWTJ, 6(3): 189-194.

[61] Ostad-Ali-Askari K. Groundwater. Horoufchin publisher, First Edition, 2015. ISBN: 978-600-7419-33-5. Isfahan, Iran.

[62] Ostad-Ali-Askari K. Nitrate pollution in groundwater. Horoufchin publisher, First Edition, 2015. ISBN: 978-600-7419-23-6. Isfahan, Iran.

[63] Ostad-Ali-Askari, K., Shayannejad, M. 2015, Developing an Optimal Design Model of Furrow Irrigation Based on the Minimum Cost and Maximum Irrigation Efficiency. International Bulletin of Water Resources \& Development, 3(2), 18-23.

[64] Ostad-Ali-Askari, K., Shayannejad, M. 2015, Optimal design of pressurized irrigation laterals installed on sloping land. International Journal of Agriculture and Crop Sciences, ISSN 2227-670X. 8(5), 792-797.

[65] Ostad-Ali-Askari, K., Shayannejad, M. 2015, Presenting a Mathematical Model for Estimating the Deep Percolation Due to Irrigation. International Journal of Hydraulic Engineering, 4(1), 17-21. DOI: 10.5923/j.ijhe.20150401.03.

[66] Ostad-Ali-Askari, K., Shayannejad, M. 2015, The Reviews of Einstein's Equation of Logarithmic Distribution Platform and the Process of Changes in the Speed Range of the Karkheh River, Khuzestan province, Iran. International Journal of Development Research, 5(3), 3786-3790.

[67] Ostad-Ali-Askari, K., Shayannejad, M. 2015, The Study of Mixture Design for Foam Bitumen and the Polymeric and Oil Materials Function in Loose Soils Consolidation. Journal of Civil Engineering Research, 5(2), 39-44. DOI: 10.5923/j.jce.20150502.04

[68] Ostad-Ali-Askari, K., Shayannejad, M. 2015, Usage of rock fill dams in the HEC-RAS software for the purpose of controlling floods. American Journal of Fluid Dynamics, 5(1), 23-29. DOI: 10.5923/j.ajfd.20150501.03. 
[69] Ostad-Ali-Askari, K., Shayannejad, M., Ghorbanizadee-Kharazi, H. 2015, Assessment of artificial neural network performance and exponential regression in prediction of effective rainfall, International Journal of Development Research, 5(3), 3791-3794.

[70] Ostad-Ali-Askari, K.,Shayannejad, M. 2015, Study of sensitivity of Autumnal wheat to under irrigation in Shahrekord, Shahrekord City, Iran. International Journal of Agriculture and Crop Sciences, 8 (4), $602-605$.

[71] Ouellet-Plamondon, C., Chazarenc, F., Comeau, Y., \&Brisson, J. (2006). Artificial aeration to increase pollutant removal efficiency of constructed wetlands in cold climate. Ecological Engineering, 27(3), 258264.

[72] Ouellet-Plamondon, C., Chazarenc, F., Comeau, Y., \&Brisson, J. 2006. Artificial aeration to increase pollutant removal efficiency of constructed wetlands in cold climate. Ecological Engineering, 27(3), 258264.

[73] Pries, J. H., Borer, R. E., Clarke Jr, R. A., \& Knight, R. L. (1996). Performance and design considerations of treatment wetland systems for livestock wastewater management in cold climate regions in the Northern United States and Southern Canada. In Proceedings of the 2nd National Workshop on Constructed Wetlands for Animal Waste Management, May (pp. 15-18).

[74] Pries, J. H., Borer, R. E., Clarke Jr, R. A., \& Knight, R. L. (1996). Performance and design considerations of treatment wetland systems for livestock wastewater management in cold climate regions in the Northern United States and Southern Canada. In Proceedings of the 2nd National Workshop on Constructed Wetlands for Animal Waste Management, May (pp. 15-18).

[75] QDNR (Queensland Department of Natural Resources). Guidelines for Using FreewaterSurface Constructed Wetlands to Treat Municipal Sewage; QDNR: Brisbane, Austral is, 2000.

[76] Ran, N., Agami, M., \&Oron, G. (2004). A pilot study of constructed wetlands using duckweed $(<\mathrm{i}>$ Lemnagibba $</ \mathrm{i}>$ L.) for treatment of domestic primary effluent in Israel. Water Research, 38(9), 22412248.

[77] Ray, A. M., \& Inouye, R. S. (2007). Development of vegetation in a constructed wetland receiving irrigation return flows. Agriculture, ecosystems \& environment, 121(4), 401-406.

[78] Rivas Hernández, A., Rivas Acosta, I., and Eslamian, S., .2015, Treatment Wetlands: Fundamentals, Urban Water Reuse Handbook, Ch. 54, and Ed. By Eslamian, S., Taylor and Francis, CRC Group, 703716.

[79] Saket, R. K. and Eslamian, S., 2015, Use of Wastewater for Hydroelectric Power Generation, Urban Water Reuse Handbook, Ch. 63, Ed. By Eslamian, S., Taylor and Francis, CRC Group, 827-838.

[80] Sayedipour, M., Ostad-Ali-Askari, K., Shayannejad, M. 2015, Recovery of Runoff of the Sewage Refinery, a Factor for Balancing the Isfahan-Borkhar Plain Water Table in Drought Crisis Situation in Isfahan Province-Iran. American Journal of Environmental Engineering, 5(2): 43-46. DOI: 10.5923/j.ajee.20150502.02

[81] Seidel, K. (1955). Die Flechtbinse (Scirpuslacustris L.). In Ökologie, Morphologie und Entwicklung, ihreStellungbei den Volkern und ihrewirtschaftlicheBedeutungn (pp. 37-52). Stuttgart, Germany: SchweizerbartischeVerlagsbuchnadlung.

[82] Seidel, K., Happel, H., \&Graue, G. (1978). Contributions to revitalization of waters (2nd ed.). KrefeldHulserberg, Germany: Max Plank Institute.

[83] Shayannejad M, Eslamian S, Gandomkar A, Marani-Barzani M, Amoushahi-Khouzani M, Majidifar Z, Rajaei-Rizi F, Kazemi M, P. Singh V, Dehghan SH, Shirvani-Dastgerdi H.R, Norouzi H, Ostad-Ali-Askari K. 2017, A Proper Way to Install Trapezoidal Flumes for Measurements in Furrow Irrigation Systems. International Journal of Research Studies in Agricultural Sciences (IJRSAS), 3(7): 1-5.

[84] Shayannejad M, Ostad-Ali-Askari K, Eslamian S, et al. 2017, Flow Hydraulic Investigation of the Wastewater on the Soil and Magnetic Field Effects in This Field. International Journal of Constructive Research in Civil Engineering (IJCRCE), 3(3): 1-15.

[85] Shayannejad M, Ostad-Ali-Askari K, Ramesh A, Singh V.P., Eslamian S. 2017, Wastewater and Magnetized Wastewater Effects on Soil Erosion in Furrow Irrigation. International Journal of Research Studies in Agricultural Sciences (IJRSAS), 3(8): 1-14. http://dx.doi.org/10.20431/2454-6224.0308001.

[86] Shayannejad M, Ostad-Ali-Askari K. Modeling of solute movement in groundwater. Kankash publisher. First edition, 2015. ISBN: 978-600-136-256-9. Isfahan, Iran.

[87] Shayannejad M, Ostad-Ali-Askari K. Optimization and its application in water resources management. Kankash publisher. First edition, 2015. ISBN: 978-600-136-248-4. Isfahan, Iran.

[88] Shayannejad M, Soltani-Toudeshki A.R, Arab M.A, Eslamian S, Amoushahi-Khouzani M, MaraniBarzani M, Ostad-Ali-Askari K. 2017, A Simple Method for Land Grading Computations and its 
Comparison with Genetic Algorithm (GA) Method. International Journal of Research Studies in Agricultural Sciences (IJRSAS), 3(8): 26-38.

[89] Shayannejad, M. Akbari, N. and Ostad-Ali-Askari, K. 2015, Determination of the nonlinear Muskingum model coefficients using genetic algorithm and numerical solution of the continuity. Int. J. of Science: Basic and Applied Research, 21(1),1-14.

[90] Shayannejad, M., Akbari, N., Ostad-Ali-Askari, K. 2015, Study of modifications of the river physical specifications on muskingum coefficients, through employment of genetic algorithm. International Journal of Development Research, 5(3), 3782-3785.

[91] Shayannejad, M., Ostad-Ali-Askari, K. 2015, Effects of magnetized municipal effluent on some chemical properties of soil in furrow irrigation. International Journal of Agriculture and Crop Sciences, 8(3), 482489.

[92] ShayannejadM, Ostad-Ali-Askari K, Eslamian S, et al. 2017, Development of a new method for determination of infiltration coefficients in furrow irrigation with natural non-uniformity of slope. Sustain. Water Resour. Manag., 3(2): 163-169.

[93] Shojaei N, Shafaei-Bejestan M, Eslamian S, Marani-Barzani M, P. Singh V, Kazemi M, Ostad-Ali-Askari K. 2017, Assessment of Drainage Slope on the Manning Coarseness Coefficient in Mountain Area. International Journal of Constructive Research in Civil Engineering (IJCRCE), 3(1): 33-40.

[94] Spangler, K., Sloey, W., \& Fetter, C. W. (1976). Experimental use of emergent vegetation for the biological treatment of municipal wastewater in Wisconsin. In J.Tourbier\& R. W. Pierson (Eds.), Biological control of water pollution (pp. 161-171). Philadelphia, PA: University of Pennsylvania Press.

[95] Terzakis, S., Fountoulakis, M. S., Georgaki, I., Albantakis, D., Sabathianakis, I., Karathanasis, A. D., ... \&Manios, T. (2008). Constructed wetlands treating highway runoff in the central Mediterranean region. Chemosphere, 72(2), 141-149.

[96] U.S. Environmental Protection Agency (U.S. EPA) (1988). Constructed wetlands and aquatic plant systems for municipal wastewater treatment (EPA/625/1-88/022). Cincinnati, OH: U.S. Environmental Protection Agency, Office of Research and Development.

[97] U.S. Environmental Protection Agency (U.S. EPA). 2004a. Guidelines for water reuse (EPA/625/R 04/108). Washington, DC: U.S. Environmental Protection Agency and U.S. Agency for International Development.

[98] U.S. Environmental Protection Agency (U.S. EPA). 2012. Guidelines for water reuse (EPA/600/R 12/618). Washington, DC: U.S. Environmental Protection Agency and U.S. Agency for International Development.

[99] Vymazal, J. (2010). Constructed wetlands for wastewater treatment. Water, 2(3), 530-549.

[100]Vymazal, J. Constructed wetlands with horizontal sub-surface flow and hybrid systems for wastewater treatment. Ecol. Eng.2005, 25, 478-490.

[101]Vymazal, J. Removal of nutrients in various types of constructed wetlands. Sci. Tot. Environ. 2007, 380, 48-65.

[102]Vymazal, J. Types of Constructed Wetlands fo $r$ Wastewater Treatment: Their Potential for Nutrient Removal. In Transformations of Nutrients in Natural and Constructed Wetlands; Vymazal, J., Ed.; Backhuys Publishers: Leiden, the Netherlands, 2001; pp. 1-93.

[103]Vymazal, J.; Kröpfelová, L. Is Concentration of Dissolved Oxygen a Good Indicator of Processes in Filtration Beds of Horizont al-flow Constructed Wetlands? In Wastewater Treatment, Plant Dynamics and Management; Vymazal, J., Ed.; Springer: Do rdrecht, The Netherlands, 2008; pp. 311-317.

[104]Vymazal, J.; Kröpfelová, L. Wastewater Treatment in Constructed Wetlands with Horizontal Sub-Surface Flow; Springer: Dordrecht, The Netherlands, 2008.

[105]Vymazal, J.; Kröpfelová, L. Wastewater Treatment in Constructed Wetlands with Horizontal Sub-Surface Flow; Springer: Dordrecht, the Netherlands, 2008.

[106]Werker, A. G., Dougherty, J. M., McHenry, J. L., \& Van Loon, W. A. (2002). Treatment variability for wetland wastewater treatment design in cold climates. Ecological Engineering, 19(1), 1-11.

[107]Wittgren, H. B., \&Maehlum, T. 1997. Wastewater treatment wetlands in cold climates. Water Science and Technology, 35(5), 45-53.

[108]Wolverton, B. C. (1987). Artificial marshes for wastewater treatment. In K. R. Reddy \& W. H. Smith (Eds.), Aquatic plants for water treatment and resource recovery (pp. 141-152). Orlando, FL: Magnolia Publishing.

[109]World Health Organisation (Ed.). (2006). WHO Guidelines for the Safe Use of Wasterwater Excreta and Greywater (Vol. 3). World Health Organization.

[110]Yue Zhang (2012), Design of a Constructed Wetland for Wastewater Treatment and Reuse in Mount Pleasant, Utah. All Graduate Plan B and other Reports. Paper 216. 
[111]Zhang, Y. 2012. Design of a Constructed Wetland for Wastewater Treatment and Reuse in Mount Pleasant, Utah.

Citation: M. Ghasemi-Zaniani et al., " Irrigation with Waste Water Treated by Constructed Wetlands ", International Journal of Research Studies in Agricultural Sciences, vol. 3, no. 11, p. 18-34, 2017. http://dx.doi.org/10.20431/2454-6224.03011002

Copyright: (C) 2017 Authors. This is an open-access article distributed under the terms of the Creative Commons Attribution License, which permits unrestricted use, distribution, and reproduction in any medium, provided the original author and source are credited. 